\title{
Pond canopy cover: a resource gradient for anuran larvae
}

\author{
LUIS SCHIESARI \\ Department of Ecology and Evolutionary Biology, The University of Michigan, Ann Arbor, MI, U.S.A.
}

\section{SUMMARY}

1. The gradient in pond canopy cover strongly influences freshwater species distributions. This study tested the effects of canopy cover on the performance of two species of larval anurans, a canopy cover generalist (Rana sylvatica, the wood frog) and an open-canopy specialist (R. pipiens, the leopard frog), and tested which factors co-varying with canopy cover mediate these effects.

2. A field transplant experiment demonstrated that canopy cover had negative performance effects on both species. However, leopard frogs, which grow faster than wood frogs in open-canopy ponds, were more strongly affected by closed-canopy pond conditions.

3. Closed-canopy ponds had lower temperature, dissolved oxygen (DO), and food nutritional quality as indicated by carbon-to-nitrogen ratio $(\mathrm{C}: \mathrm{N})$ analysis of fieldsampled food types, and of gut contents of transplanted larvae.

4. Laboratory experiments demonstrated that higher temperature and food quality but not DO substantially increased larval growth. However, only food quality increased growth rates of leopard frogs more than wood frogs.

5. The strong correlation of growth rates to gut content $\mathrm{C}: \mathrm{N}$ in the field, and the similarity of growth curves as a function of resource quality in the field and laboratory, strongly suggest that resources are of primary importance in mediating intraspecific, and especially interspecific differences in performance across the canopy cover gradient.

Keywords: abiotic factors, anuran larvae, canopy cover, performance, resources

\section{Introduction}

Comparative studies of species performances across environmental gradients can greatly enhance our ability to understand the factors influencing species success in nature (e.g. Connell, 1975; Menge \& Sutherland, 1976, 1987; Wellborn, Skelly \& Werner, 1996). One gradient that strongly influences species performance is the gradient in forest canopy cover, mainly through its effects on light intensity and hence primary productivity. Despite the historical importance that canopy gradients have had in terrestrial ecology (e.g. in forest succession; Clements, 1916;

Correspondence: L. Schiesari, Present address: Environmental Management, School of Arts, Sciences and Humanities, University of São Paulo (EACH - USP), Av. Arlindo Bétio 1000, Parque Ecológico do Tietê, 03828-080, São Paulo-SP, Brazil. E-mail: 1schiesa@usp.br
Horn, 1974; Augspurger, 1984; Kobe, Pacala \& Silander, 1995), it was not until relatively recently that they became a focus of study by freshwater ecologists, especially those working in lentic systems (Bussler, 1982; Werner \& Glennemeier, 1999; Skelly, Freidenburg \& Kiesecker, 2002; Halverson et al., 2003). Nevertheless, ponds in forested landscapes can be heavily shaded by the surrounding terrestrial vegetation, with strong impacts on a variety of abiotic and biotic properties that could affect aquatic community composition. Closed-canopy ponds receive lower incident solar radiation, and have lower temperatures and dissolved oxygen (DO) levels than open-canopy ponds (Werner \& Glennemeier, 1999; Skelly et al., 2002; Halverson et al., 2003). Furthermore, whereas DO is low and constant throughout the day in closedcanopy ponds, open-canopy pond DO displays sharp diel fluctuations, reaching supersaturated concentrations early in the afternoon (Werner \& Glennemeier, 
1999). These observations suggest that primary productivity is higher in open-canopy ponds, as are the standing crop and diversity of periphyton and macrophytes (Skelly et al., 2002; L.S., pers. obs.). Consequently, resource quantity should be greater in open-canopy ponds. In addition, resource types available to consumers appear to shift from algae and macrophytes in open-canopy ponds to detritus (i.e. decomposing leaf-litter) in closed-canopy ponds.

Canopy cover has a strong influence on freshwater community composition. A long-term survey conducted in Southern Michigan revealed that the gradient is important in influencing the spatial distributions of organisms as diverse as amphibian larvae, beetle larvae, odonate naiads and snails (Skelly, Werner \& Cortwright, 1999, E.E. Werner, pers. comm.). Furthermore, historical records indicated that increases in canopy cover accompanying forest succession promoted major temporal changes in the distributions of amphibian species, leading to an overall impoverishment of local communities (Skelly et al., 1999). This impoverishment appears to occur because most species are intolerant to closed-canopy pond conditions, but it is not clear which factor or factors co-varying with canopy cover drive these strong distributional differences.

In this paper I investigate how canopy cover affects species performance, and what factors contribute to these performance effects. I employed as the study system a pair of congeneric larval anurans that overlap in range, breeding phenology, and developmental period, but segregate habitat across the canopy cover gradient. Leopard frogs (Rana pipiens Schreber) are restricted to open-canopy ponds, whereas wood frogs (Rana sylvatica LeConte) are found throughout the canopy cover gradient. I transplanted both species to enclosures in open and closedcanopy ponds to test the hypothesis that canopy cover reduces individual performance, but that this reduction is greater for the open-canopy specialist than for the canopy cover generalist. Although similar tests to this hypothesis have been conducted before (Werner \& Glennemeier, 1999; Skelly et al., 2002), I used this experiment to test the hypothesis that canopy cover is a gradient in resource nutritional quality by analysing the carbon-to-nitrogen ratios $(\mathrm{C}: \mathrm{N})$ of the food consumed by enclosed larvae. I further examined the sources of variation in this resource nutritional quality by analysing field-sampled substrates repor- ted to constitute the majority of generalised tadpoles' diets.

I then investigated which factor or factors mediate these performance effects by comparing species responses to canopy cover in the field experiment, with species responses to manipulations of abiotic (DO, temperature) and biotic (food nutritional quality) factors in the laboratory. A reduction in DO was predicted to lead to slower growth because of greater stress, and because repeatedly surfacing for air bobbing diverts time that could be devoted to foraging, and diverts energy that could be allocated to growth (Feder, 1984; Feder \& Moran, 1985). A reduction in temperature was predicted to lead to slower growth by lowering metabolic and foraging rates (Eckert \& Randall, 1983; Burggren \& Just, 1992). Finally, a reduction in resource quality was predicted to lead to slower growth by reducing the availability of nutrients per unit food mass. Because all three factors tested are predicted to influence wood frog and leopard frog performance in the same direction, the most important factors should explain both intraspecific and especially interspecific variation in growth performance across the canopy cover gradient.

\section{Methods}

\section{Field experiment}

I conducted a field transplant experiment to test the effects of canopy cover on the performance of wood frog and leopard frog tadpoles in a set of four ponds, two closed-canopy [West Woods Big (WWB) and Southwest Woods (SWW)] and two open-canopy [Fishhook Marsh (FH) and Independence Marsh (IND)]. WWB, SWW, and FH are located in the E.S. George Reserve of the University of Michigan near Pinckney, MI, U.S.A. $\left(42^{\circ} 28^{\prime} \mathrm{N}, 84^{\circ} 00^{\prime} \mathrm{W}\right)$. Independence Marsh is located in the Independence Lake County Park, Webster, MI, U.S.A. WWB and SWW support populations of wood frogs, IND supports populations of leopard frogs, and FH supports populations of both species.

Frog larvae were hatched from multiple egg masses ( $>12$ for each species) collected in IND (leopard frogs) and in a pond near Pinckney, Michigan (wood frogs). All tadpoles were reared in 300-L wading pools and fed rabbit chow ad libitum until used in the experiments. 
Between 13 and 15 June 2001 I placed four enclosures in each pond; care was taken not to disturb the substrate or the vegetation structure in the enclosed area. Enclosures were constructed of a wooden frame $\left(1.5 \times 0.8 \times 1.0 \mathrm{~m} ; 1.24 \mathrm{~m}^{2}\right)$ to which fibreglass window screening $(1 \times 1.5 \mathrm{~mm}$ mesh) was stapled. Enclosures were open at the bottom, so that tadpoles could forage on the pond natural benthos. To prevent tadpoles from escaping, enclosures were firmly staked to the bottom of the pond and sealed with sediment and bricks placed along a $30 \mathrm{~cm}$ wide fibre glass screening skirt added to the external lower edge of each enclosure. I estimated canopy cover by spherical densiometer (Forestry Suppliers, Jackson, MS, U.S.A.) measurements taken in four directions $(\mathrm{N}, \mathrm{S}, \mathrm{E}, \mathrm{W})$ over each enclosure.

On 19 June, each enclosure was stocked with 30 wood frogs $[314.8 \pm 5.2 \mathrm{mg}$ (mean mass $\pm 1 \mathrm{SE}$ )] and 30 leopard frogs $(329.5 \pm 15.2 \mathrm{mg}$; developmental stages not recorded). Each enclosure was stocked with both species to control for environmental patchiness in availability of resources, which would decrease the power of interspecific comparisons of diet. Because prior to the experiment zooplankton and periphyton developed to varying densities in tadpole cultures, I separated the four replicates in each pond in two blocks based on culture type (tadpoles from either cultures with high periphyton cover and low zooplankton densities or cultures with low periphyton cover and high zooplankton densities). Each of the two blocks was randomly assigned to the four enclosures in each pond.

The experiment was terminated after 15 (SWW and WWB), 16 (IND) or 17 days (FH), when wood frogs reached advanced developmental stages. Tadpoles were dipnetted out of the enclosures and immediately killed in $20 \%$ cold ethanol to halt ingestion of additional food and digestion of gut contents. In the laboratory tadpoles were counted, weighed, staged (according to Gosner, 1960), and frozen.

As an index of the nutritional quality of food ingested in nature, I analysed the $\mathrm{C}: \mathrm{N}$ of the foregut content of three individuals per species, in each of three enclosures per pond. Variation in $\mathrm{C}: \mathrm{N}$ in a sample more directly reflects variation in $\% \mathrm{~N}$ than in $\% C$ (Sterner \& Elser, 2002; see also Schiesari, 2004), and therefore $\mathrm{C}: \mathrm{N}$ can be used as an inverse index of resource quality provided that tadpole growth is dependent on proteins but not carbohydrates. This latter assumption was supported in controlled laboratory experiments manipulating purified artificial diets (Schiesari, 2004). I controlled for potential mass effects on diet by analysing tadpoles around $1200 \mathrm{mg}$ wet mass; this target mass could not be met for leopard frogs in open-canopy ponds, which were on average three times heavier. For each individual, I dissected the foregut (typically the first $2-3 \mathrm{~cm}$ ) and removed its contents, which were dried and analysed for $\% \mathrm{C}, \% \mathrm{~N}$, and therefore $\mathrm{C}: \mathrm{N}$ (percentages and ratio by weight) in a Thermo Instrument Flash elemental analyser 1112 series (CE Elantech, Inc., Lakewood, NJ, U.S.A.).

\section{Survey of food quality in natural ponds}

To identify the sources of variation in food nutritional quality across the canopy cover gradient, I sampled the food types reported to constitute the majority of generalised pond tadpoles' diets (detritus, periphyton and phytoplankton; Alford, 1999). These food types were sampled in June and July 1999 in three closedcanopy ponds (SWW, WWB, and Red Maple Swamp) and three open-canopy ponds (Southwest Swamp, Cattail Marsh, and Experimental Pond 1) in the E. S. George Reserve.

To sample phytoplankton, a $500 \mathrm{~mL}$ sample of subsurface water was collected in each pond and sampling month, and passed through a $150 \mu \mathrm{m}$ mesh to remove larger zooplankton. This sample was filtered through a precombusted Whatman GF/F fibreglass filter. Periphyton was collected in periphytometers (Skelly et al., 2002). In each pond, three periphytometers were left for a period of 15 days per sampling month, after which slides were scraped with a razorblade, washed, and the resulting suspension filtered through a precombusted Whatman GF/F fibreglass filter. Detritus in closed-canopy ponds consisted of tree leaf-litter (mainly Quercus spp.), whereas in open-canopy ponds detritus included more commonly decomposing aquatic macrophytes or indistinct sediment. Three samples of the most representative detritus type in each pond were collected per sampling month. In addition, because tadpoles scrape leaf surfaces (L.S., pers. obs.), in the first sampling month I also separately sampled detritus biofilm by softly scraping leaves with a razorblade. All samples were oven-dried, and analysed for $\% \mathrm{C}, \% \mathrm{~N}$, and therefore $\mathrm{C}: \mathrm{N}$ ratio (percentages and 
ratio by weight) in a Perkin-Elmer $2400 \mathrm{CHN}$ Elemental Analyzer (Perkin-Elmer Inc., Wellesley, MA, U.S.A.).

\section{Laboratory experiments}

I conducted three laboratory experiments to separate the effects of food nutritional quality, temperature and DO on larval growth performance.

Frog larvae were hatched from multiple egg masses ( $>6$ for each species) collected in the ESGR. All tadpoles were reared in 300-L wading pools and fed rabbit chow ad libitum until used in the experiments.

Food nutritional quality. Foods varying in nutritional quality were obtained by mixing ground leaf-litter detritus, Purina rabbit chow (Purina Mills, Saint Louis, MO, U.S.A.; approximately $16 \%$ protein) and TetraMin fish flakes (Tetra Werke, Melle, Germany; approximately $45 \%$ protein) in four diets: $25 \%$ detritus $+75 \%$ chow; $100 \%$ chow; $75 \%$ chow $+25 \%$ fish flakes; $50 \%$ chow $+50 \%$ fish flakes (percentages by dry mass). Food was provided in daily rations equivalent to $24 \%$ of the initial body mass of tadpoles. This food quantity exceeds tadpole consumption rates (L.S., pers. obs.) and thus any differences in growth can be attributed to food nutritional quality only.

The experiment followed a factorial, randomised block design crossing the two species and four food qualities. It was conducted in 9.5-L boxes filled with aged well water and placed in shelves in the laboratory following a $14 \mathrm{~h}$ light : $10 \mathrm{~h}$ dark photoperiod. Each box contained either 10 leopard frogs (initial mass $198.21 \pm 36.06 \mathrm{mg})$ or 10 wood frogs $(192.30 \pm$ $30.32 \mathrm{mg}$ ). Each treatment was replicated four times. I blocked the experiment by shelf height because of a small $\left({ }^{\circ} \mathrm{C}\right)$ but noticeable vertical gradient in temperature in the laboratory. The experiment started 10 June 1999 and was terminated after 12 days. Food was provided every other day and water was changed every 4 days. Mean air temperature was $19.3 \pm 1.5^{\circ} \mathrm{C}$.

For estimation of diets nutritional qualities, four samples of each ingredient were oven-dried and analysed for $\% \mathrm{~N}$ (by weight) in a Perkin-Elmer 2400 $\mathrm{CHN}$ Elemental Analyzer. Approximate estimates of protein content of each food mixture were obtained by multiplying mean $\% \mathrm{~N}$ by a factor of 6.25 (Sterner \& Elser, 2002).
Abiotic factors. Prior to the experiments, temperature and DO in open- and closed-canopy ponds were measured with a multimeter (WTW GmbH, Weilheim, Germany) to calibrate abiotic parameters in the experiment within realistic levels.

Both experiments were conducted in 9.5-L boxes filled with aged well water and placed in shelves in the laboratory following a $14 \mathrm{~h}$ light: $10 \mathrm{~h}$ dark photoperiod. Each box contained either 10 leopard frogs (initial mass $85.3 \pm 10.2 \mathrm{mg}$ in the temperature experiment, $92.7 \pm 15.3 \mathrm{mg}$ in the $\mathrm{DO}$ experiment) or 10 wood frogs $(85.8 \pm 13.0 \mathrm{mg}$ in the temperature experiment, $94.0 \pm 15.1 \mathrm{mg}$ in the DO experiment). Food consisted of a ground mixture of $75 \%$ Purina rabbit chow $+25 \%$ TetraMin fish flakes. Because resource availability was expected to vary with canopy cover I also manipulated food quantity using low and moderate quantity treatments, namely, daily rations equivalent to $4 \%$ and $12 \%$ of the initial body mass of tadpoles. Food was provided every other day.

The experiment manipulating temperature was conducted in environmental chambers and followed a factorial, randomised design crossing the two species, two nominal temperatures $\left(14{ }^{\circ} \mathrm{C}\right.$ and $18{ }^{\circ} \mathrm{C}$ ), and two food levels. Each treatment was replicated four times. The experiment started 18 May 2001 and was terminated after 11 days.

The experiment manipulating $\mathrm{DO}$ followed a factorial, randomised block design crossing the two species, two food levels, and three DO manipulations. DO was reduced by bubbling pre-purified nitrogen (Cryogenic Gases, Detroit, MI, U.S.A.) in experimental containers (McIntyre \& McCollum, 2000). Because the mechanical disturbance of bubbling itself may affect tadpole behaviour and performance (L.S., pers. obs.), I included a sham control in which air instead of $\mathrm{N}_{2}$ was bubbled. The regular control was simply a tank with no bubbling. Each treatment was replicated four times. The experiment was blocked by shelf height. It started on 16 May 2001 and ended after 10 days. DO levels in all tanks were monitored regularly throughout the experiment and adjusted when necessary. Mean air temperature was $24.0 \pm 2.4^{\circ} \mathrm{C}$.

\section{Analyses}

For the field experiment I employed as response variables enclosure means of survivorship, final developmental stage, specific growth rates $[g=$ 
$\ln$ (final mass) - $\ln$ (initial mass)/time elapsed], and foregut content $C: N$. Survivorship responses are not reported in this article because predators were trapped in some enclosures leading to substantial tadpole mortality; thus the effects of pond type and predator presence on survivorship are confounded. Whereas differences in survivorship might influence growth through changes in per capita resource availability or in the intensity of cannibalism or necrophagy, this influence did not seem to be important. Survivorship was unrelated to growth rates (Pearson's $r=0.23, P=0.262, n=26$ enclosures) or to tadpole trophic level as estimated from the ${ }^{15} \mathrm{~N}$ isotopic signatures of enclosed larvae relative to reference herbivores $(r=0.002, P=0.994, n=21$ enclosures; Schiesari, 2004). I employed separate nested ANOVAs for each response variable using species, pond type (open- or closed-canopy), pond (nested within pond type), and block as factors. An ANCOVA was conducted to determine whether species, foregut content $\mathrm{C}: \mathrm{N}$ (covariate), or their interaction contribute to growth rates in the field.

Similarly, in the laboratory experiment manipulating diets I conducted an ANCOVA to determine whether species, food protein content (covariate), or their interaction contribute to growth rates. An ANOVA evaluated the effects of food type (detritus, periphyton and phytoplankton), pond type and their interaction on $\mathrm{C}: \mathrm{N}$. Growth responses to variation in abiotic factors in the laboratory experiments were also analysed with ANOVA using species, food level, treatment (temperature or DO treatments), and their interactions as factors and growth rates as the response variable. In all analyses, dependent variables were checked for assumptions of linearity, normality, and homogeneity of variances.

\section{Results}

\section{Field transplant experiment}

The study ponds differed significantly in canopy cover (Fig. 1a; ANOvA $F_{3,15}=275.9, P<0.001$ ). Tukey's multiple comparisons test indicated that canopy cover was significantly greater in the closed-canopy ponds (WWB and SWW) than in the open-canopy ponds (FH and IND).

Tadpole specific growth rates were significantly affected by canopy cover, species and their interaction

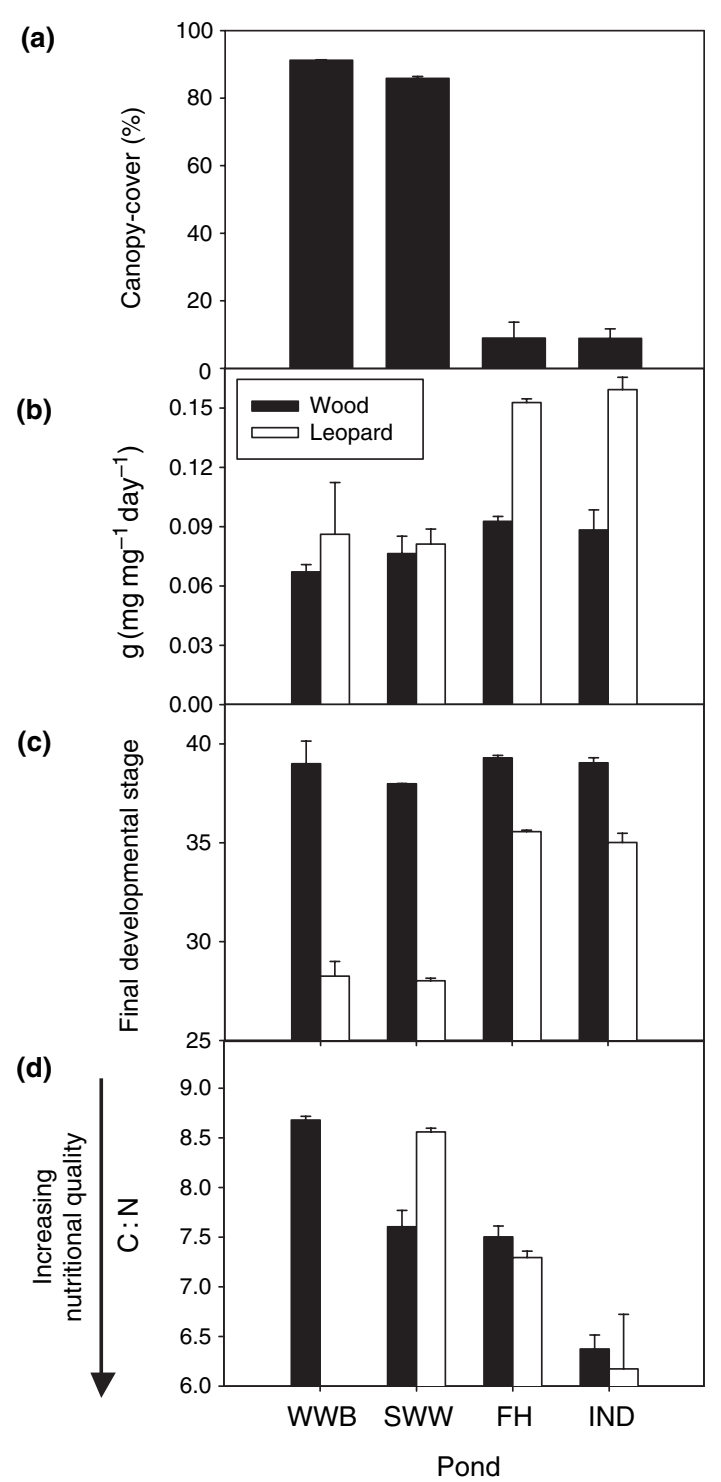

Fig. 1 Results of the field experiment transplanting wood frog and leopard frog larvae to two closed-canopy and two opencanopy ponds. (a) Canopy cover over enclosures, (b) specific growth rate, (c) Gosner's final developmental stage (stage 45 corresponds to completion of metamorphosis), and (d) Carbonto-nitrogen ratio of foregut contents of wood frog (solid bars) and leopard frog larvae (open bars) in the four ponds studied. Bars represent the grand mean \pm 1 SE of replicate enclosures. Some replicates were lost because of predation by trapped salamander larvae, leading to unequal number of replicates (WWB: 3 for wood frogs / 2 for leopard frogs; SWW: 2/2; FH: 4/ 4, IND 4/4). Only three leopard frogs survived in WWB; they lacked any contents in their foreguts.

(Table 1; Fig. 1b). Tadpoles of both species grew faster in open-canopy ponds, and leopard frogs grew faster than wood frogs. The significant species-by-canopy 
Table 1 Results of ANOva for the effects of canopy (open- versus closed), pond (nested within canopy), species, and a canopy-byspecies interaction term on the specific growth rates, final developmental stage, and gut content $\mathrm{C}: \mathrm{N}$ of enclosed wood frog and leopard frog larvae. Non-significant block effects were dropped from the analyses.

\begin{tabular}{|c|c|c|c|c|c|c|c|}
\hline \multirow[b]{2}{*}{ Factor } & \multirow[b]{2}{*}{ d.f. } & \multicolumn{2}{|l|}{ Growth } & \multicolumn{2}{|l|}{ Stage } & \multicolumn{2}{|l|}{$C: N$} \\
\hline & & $F$-value & $P$-value & $F$-value & $P$-value & $F$-value & $P$-value \\
\hline Canopy & 1 & 50.7 & 0.000 & 42.8 & 0.000 & 54.1 & 0.000 \\
\hline Pond (Canopy) & 2 & 0.4 & 0.682 & 1.0 & 0.385 & 14.0 & 0.001 \\
\hline Species & 1 & 40.9 & 0.000 & 112.2 & 0.000 & 2.4 & 0.147 \\
\hline Canopy $\times$ Species & 1 & 18.4 & 0.000 & 33.1 & 0.000 & 5.7 & 0.034 \\
\hline
\end{tabular}

cover interaction term arose because, relative to closed-canopy ponds, in open-canopy ponds growth rates increased only $23 \%$ for wood frogs, but $87 \%$ for leopard frogs. Species differed in growth rates in open-canopy ponds (one-way ANOvA $F_{1,15}=90.4$, $P<0.001)$ but not in closed-canopy ponds $\left(F_{1,9}=1.8\right.$, $P=0.218$ ).

Developmental stage at the end of the experiment was also significantly affected by canopy cover, species, and their interaction (Table 1; Fig. 1c). Wood frogs approached metamorphosis in both pond types. Leopard frog development, on the contrary, was strongly affected by canopy cover. By the end of the experiment, leopard frogs in open-canopy ponds were on average at stage 37 , but only at stage 28 in closedcanopy ponds.

Carbon-to-nitrogen ratios of tadpole foregut contents were significantly affected by canopy cover, as food consumed in closed-canopy ponds had higher $\mathrm{C}: \mathrm{N}$, and therefore lower nutritional quality, than in open-canopy ponds (Table 1; Fig. 1d). Species had no significant effects on $\mathrm{C}: \mathrm{N}$. However, a significant species-by-canopy cover interaction term was detected because wood frogs consumed food of lower $\mathrm{C}: \mathrm{N}$ than leopard frogs in the only closed-canopy pond where enough individuals of both species were available for analysis (SWW; one-way ANOVA $F_{1,11}=$ $6.6, P=0.028$ ). Consequently, wood frogs consumed food of equal $\mathrm{C}: \mathrm{N}$ in a closed-canopy pond and in an open-canopy pond (SWW versus $\mathrm{FH}$; one-way ANOvA $F_{1,14}=0.1, P=0.796$ ).

I also estimated the quality of gut contents of freeranging tadpoles to evaluate any effects of the experimental manipulation. Gut content $C: N$ of free-ranging ( $n=5$ per pond) and enclosed wood frogs did not differ in either of the two closed-canopy ponds (one-way ANOvAs, $F_{1,10}=0.1, P=0.919$ in SWW; $F_{1,9}=0.5, P=0.503$ in WWB). Free-ranging leopard frogs $(n=5)$ had marginally higher $C: N$ than enclosed leopard frogs $\left(F_{1,13}=4.5, P=0.060\right.$ in IND). Therefore the enclosure experiment appears to have given realistic estimates of the quality of food ingested by tadpoles in nature.

There was a strong relationship between foregut content $\mathrm{C}: \mathrm{N}$ and specific growth rates, as tadpoles grew faster in ponds and enclosures where the nutritional quality of food ingested was higher (Fig. 2; ANCOVA $\left.F_{1,17}=23.2, P<0.001\right)$. Species also had a significant effect as leopard frogs grew faster $\left(F_{1,17}=\right.$ $5.0, P=0.042)$. Despite the lack of a significant speciesby-C : $\mathrm{N}$ interaction term $\left(F_{1,17}=2.2, P=0.159\right)$, growth appeared to asymptote at lower food qualities in wood frogs $(90 \%$ of their maximum growth rates is

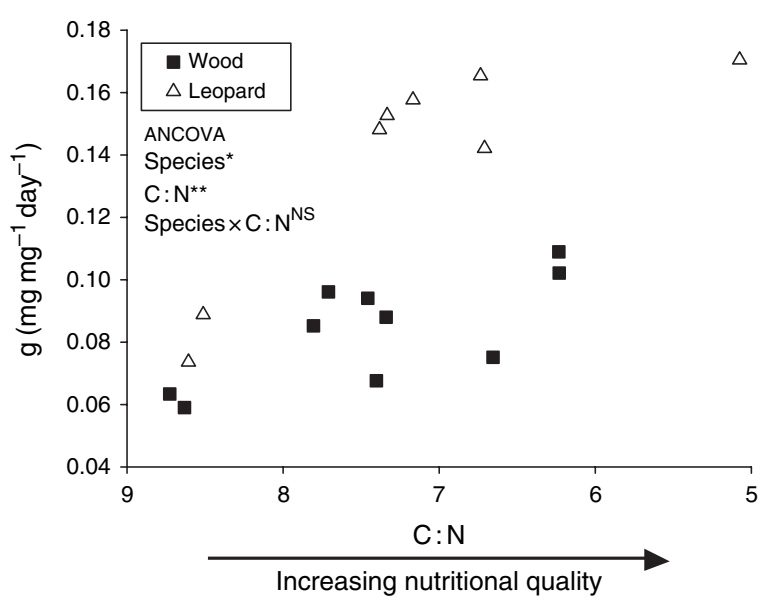

Fig. 2 Specific growth rates of wood frog (solid squares) and leopard frog larvae (open triangles) as a function of foregut content carbon-to-nitrogen ratios in the field transplant experiment. Note that growth rates of both species increase as food quality increases, but that the asymptotic growth rates of leopard frogs are higher than those of wood frogs. $\mathrm{C}: \mathrm{N}$ ratios in the $x$-axis were reversed for intuitive visualisation of increasing resource quality. Each symbol represents an enclosure mean. ANCOVA $R^{2}=0.84$. 
reached at around $\mathrm{C}: \mathrm{N}=7.7$ ) than in leopard frogs (same proportion is reached at around $\mathrm{C}: \mathrm{N}=7.3$ ).

\section{Survey of food quality in natural ponds}

An overall comparison of the nutritional quality of natural food types indicated that $\mathrm{C}: \mathrm{N}$ was significantly affected by canopy cover $\left(F_{1,43}=6.4, P=\right.$ $0.016)$, food type $\left(F_{2,43}=40.7, P<0.001\right)$, and their interaction $\left(F_{2,43}=10.1, P<0.001\right.$; Fig. 3). Sampling date was not significant and was dropped from the analysis. $\mathrm{C}: \mathrm{N}$ of detritus was significantly higher (i.e. detritus had lower nutritional quality) than $\mathrm{C}: \mathrm{N}$ of phytoplankton and periphyton (Tukey's $P<0.001$ ). $C: N$ of open-canopy pond resources was significantly lower than $\mathrm{C}: \mathrm{N}$ of closed-canopy pond resources; however, this difference was essentially because of $\mathrm{C}: \mathrm{N}$ of detritus, as no pond type differences were observed for periphyton and phytoplankton. $\mathrm{C}: \mathrm{N}$ of closed-canopy pond detritus biofilm was significantly lower than $\mathrm{C}: \mathrm{N}$ of whole leaf litter (ANOVA $F_{1,30}=$ $7.6, P=0.010)$, but still $30 \%$ higher than $C: N$ of opencanopy pond detritus (ANOVA $F_{1,25}=9.4, P=0.005$ ).

\section{Laboratory experiments: influence of food nutritional quality}

Food quality had strong positive effects on tadpole growth rates (ANCOVA $F_{1,31}=27.3, P<0.001 ;$ Fig. 4 ).

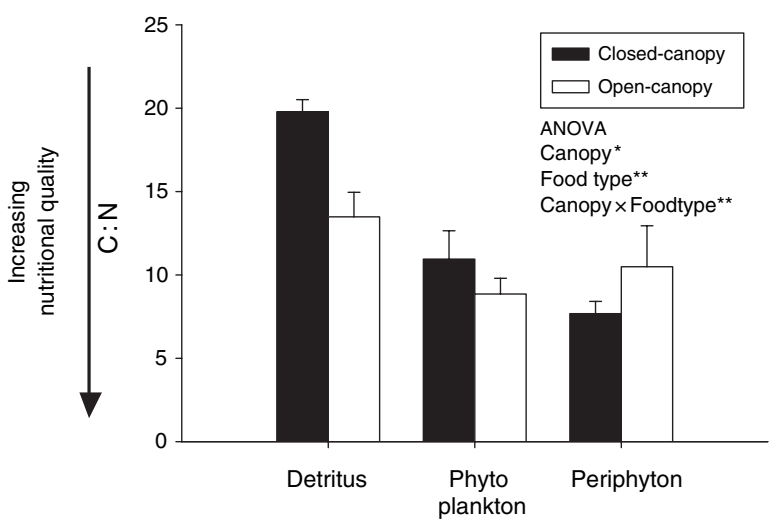

Fig. 3 Carbon-to-nitrogen ratios of the resource types reported to constitute the majority of generalised pond tadpole diets in nature. Open bars represent open-canopy pond resources, solid bars indicate closed-canopy pond resources. Bars represent mean \pm 1 SE of 16 and 10 samples of detritus, four and six samples of phytoplankton, and three and five samples of periphyton, respectively in closed- and open-canopy ponds. Detritus in closed-canopy ponds refers to whole leaves.

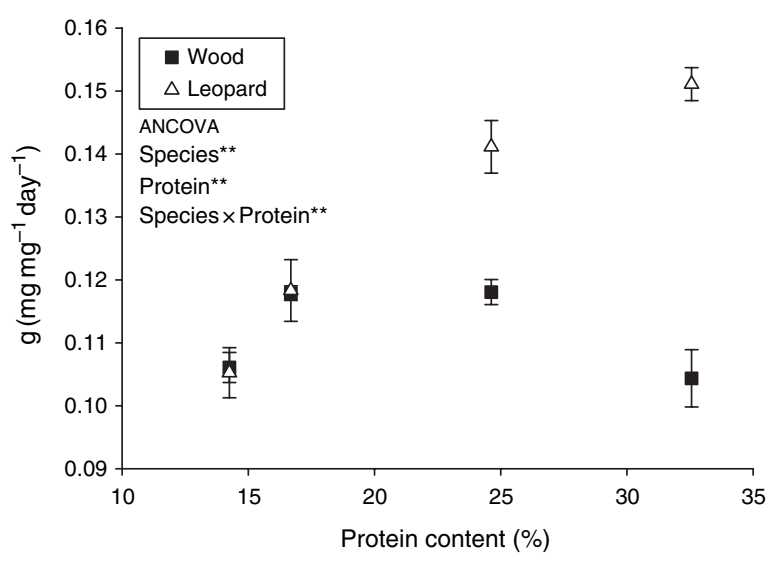

Fig. 4 Specific growth rates of wood frog (solid squares) and leopard frog larvae (open triangles) as a function of the protein content of artificial diets provided at high food levels ( $24 \%$ $\mathrm{BM} \mathrm{day}{ }^{-1}$ ). Note that, as in Fig. 2, growth rates of both species tended to increase with food quality, but the slope and asymptotic values were higher in leopard frogs. Growth curves of wood frogs tended to be parabolic because in the highest-quality diet wood frog tadpoles began to approach metamorphosis and lose mass. Each symbol represents the grand mean $\pm 1 \mathrm{SE}$ of four replicates. ANCOVA $R^{2}=0.78$. To provide a basis for comparison between Figs 2 and 4, protein content of food consumed in field enclosures ranged from $24 \%$ to $38 \%$ for wood frogs and from $19 \%$ to $54 \%$ for leopard frogs.

Leopard frogs grew faster $\left(F_{1,31}=18.4, P<0.001\right)$, and reached $28 \%$ higher maximum growth rates than wood frogs. Most importantly, a significant interaction term was detected $\left(F_{1,31}=40.7, P<0.001\right)$ as leopard frogs responded more strongly to increases in food quality than did wood frogs. In fact, wood frog growth responses tended to be parabolic; this occurred because, at the highest food quality manipulated, wood frogs had approached metamorphosis, a period associated with weight loss. Survivorship through the experiment was $99 \%$ and did not depend on species, food quality or their interaction.

\section{Laboratory experiments: influence of abiotic factors}

Open-canopy ponds were warmer than closed-canopy ponds in May 2001 (mean afternoon temperatures $\pm \mathrm{SE}$ in open-canopy ponds $16.4 \pm 0.5^{\circ} \mathrm{C}, n=$ 21 , in closed-canopy ponds $13.9 \pm 0.3{ }^{\circ} \mathrm{C}, n=16$; ANOVA $\left.F_{1,35}=15.9, P<0.001\right)$, but the differences were not significant in June 2001 (open-canopy ponds $24.9 \pm 2.1^{\circ} \mathrm{C}, n=5$, closed-canopy ponds $19.9 \pm$ $0.8^{\circ} \mathrm{C}, n=5$; ANova $F_{1,9}=3.5, P=0.097$ ). Because the experiment was conducted in mid-May, laboratory 
temperatures were set at $14^{\circ} \mathrm{C}$ (actual temperature $=$ $\left.14.4 \pm 0.1{ }^{\circ} \mathrm{C}\right)$ and $18^{\circ} \mathrm{C}\left(17.7 \pm 0.1{ }^{\circ} \mathrm{C}\right)$. Furthermore, I include in the results and analyses below species growth at $24{ }^{\circ} \mathrm{C}$ in the DO no-bubbling treatment because the source and initial size of tadpoles, period of experiment, and the food treatments, were similar across experiments.

Species identity had no main effect on specific growth rates. In contrast, growth was significantly affected by temperature, food level, and a temperature-by-food level interaction term (Table 2; Fig. 5). Temperature had a positive effect on growth rates. The interaction term arose because the effects of temperature were less pronounced at low food levels than at high food levels. In fact, at low food levels, temperature had only a non-significant $7 \%$ increase in growth rates between the two treatments most closely matching the afternoon temperatures of closed$\left(14^{\circ} \mathrm{C}\right)$ and open-canopy ponds $\left(18^{\circ} \mathrm{C}\right)$ in May 2001 (Tukey's $P=0.702$ ). On the contrary, at high food levels the same increase in temperature led to a $42 \%$ increase in growth (Tukey's $P<0.001$ ). Species identity did not interact significantly with any other factor (Table 2). Both species exhibited 100\% survival in this experiment regardless of resource levels.

Open-canopy ponds had higher DO than closedcanopy ponds in May 2001 (afternoon DO in open-canopy ponds $5.3 \pm 0.7 \mathrm{mg} \mathrm{L}^{-1}, n=21$, closedcanopy ponds $1.9 \pm 0.4 \mathrm{mg} \mathrm{L}^{-1}, n=16$; ANOVA $F_{1,35}=13.8, P=0.001$ ) but the differences were not significant in June 2001 (open-canopy ponds $3.9 \pm$ $1.3 \mathrm{mg} \mathrm{L}^{-1}, \quad n=5$, closed-canopy ponds $2.8 \pm$ $1.0 \mathrm{mg} \mathrm{L}{ }^{-1}, n=5$; ANOVA $F_{1,9}=0.5, P=0.502$ ).

In the laboratory, DO manipulations bracketed DO variation in the field. DO increased from nitrogen bubbling treatments $\left(2.2 \pm 0.1 \mathrm{mg} \mathrm{L}^{-1}\right)$ to the no-

Table 2 Results of ANOvA for the effects of temperature, food level, species, and their interactions on the specific growth rates of wood frog and leopard frog larvae

\begin{tabular}{llrl}
\hline Factor & d.f. & $F$-value & $P$-value \\
\hline Temperature (T) & 2 & 111.0 & 0.000 \\
Food (F) & 1 & 388.8 & 0.000 \\
Species (SP) & 1 & 2.0 & 0.165 \\
$\mathrm{~T} \times \mathrm{F}$ & 2 & 24.7 & 0.000 \\
$\mathrm{~T} \times \mathrm{SP}$ & 2 & 0.8 & 0.476 \\
$\mathrm{SP} \times \mathrm{F}$ & 1 & 0.3 & 0.563 \\
$\mathrm{~T} \times \mathrm{F} \times \mathrm{SP}$ & 2 & 0.0 & 0.952 \\
\hline
\end{tabular}

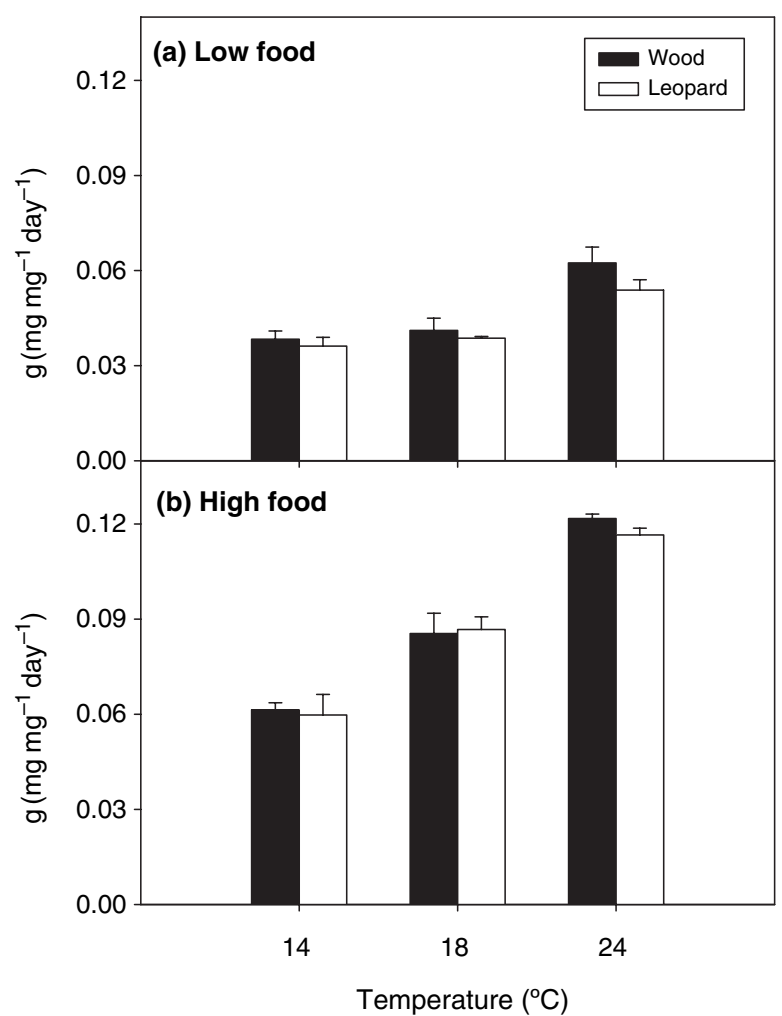

Fig. 5 Specific growth rates of wood frog (solid bars) and leopard frog larvae (open bars) as a function of temperature at (a) low food levels $\left(4 \% \mathrm{BM} \mathrm{day}^{-1}\right)$ and (b) moderately high food levels $\left(12 \% \mathrm{BM} \mathrm{day}^{-1}\right)$. Note that 14 and $18{ }^{\circ} \mathrm{C}$ respectively approximate the mean daily high temperatures of closed- and open-canopy ponds in May, when leaves have budded out and canopy-cover in woodland ponds is complete. Bars represent the grand mean $\pm 1 \mathrm{SE}$ of four replicates.

bubbling control $\left(6.8 \pm 0.2 \mathrm{mg} \mathrm{L}^{-1}\right)$ to the air bubbling sham control $\left(8.5 \pm 0.1 \mathrm{mg} \mathrm{L}{ }^{-1}, n=16\right.$ for each treatment). DO levels, food, and species identity had significant effects on tadpole specific growth rates (Table 3; Fig. 6). Overall, a decrease in DO was associated with a slight decrease in growth rates. Wood frogs tended to grow faster than leopard frogs, but only the growth rate of wood frogs decreased under low DO. This led to a nearly significant speciesby-DO interaction term. A similar analysis lumping air and nitrogen bubbling treatments suggests that bubbling itself had an effect on individual performance $\left(F_{1,47}=21.33, P<0.001\right)$, but results are qualitatively similar if only air and nitrogen bubbling treatments are compared (Table 3).

Survivorship differences between species were also detected. Whereas leopard frog survivorship was $100 \%$ at both air and nitrogen bubbling, wood frog 


\begin{tabular}{|c|c|c|c|c|c|c|}
\hline \multirow[b]{2}{*}{ Factor } & \multicolumn{3}{|c|}{ All DO treatments } & \multicolumn{3}{|c|}{ Only air and $\mathrm{N}$ bubbling } \\
\hline & d.f. & $F$-value & $P$-value & d.f. & $F$-value & $P$-value \\
\hline Dissolved oxygen (DO) & 2 & 16.0 & 0.000 & 1 & 5.9 & 0.023 \\
\hline Food $(\mathrm{F})$ & 1 & 877.5 & 0.000 & 1 & 533.7 & 0.000 \\
\hline Species (SP) & 1 & 18.6 & 0.000 & 1 & 14.2 & 0.001 \\
\hline $\mathrm{DO} \times \mathrm{F}$ & 2 & 0.4 & 0.649 & 1 & 0.3 & 0.587 \\
\hline $\mathrm{DO} \times \mathrm{SP}$ & 2 & 2.7 & 0.079 & 1 & 4.8 & 0.038 \\
\hline $\mathrm{F} \times \mathrm{SP}$ & 1 & 0.1 & 0.765 & 1 & 0.0 & 0.986 \\
\hline $\mathrm{DO} \times \mathrm{F} \times \mathrm{SP}$ & 2 & 0.3 & 0.733 & 1 & 0.4 & 0.511 \\
\hline
\end{tabular}

Table 3 Results of ANOVA for the effects of dissolved oxygen, food level, species, and their interactions on the specific growth rates of wood frog and leopard frog larvae. Non-significant block effects dropped from the analysis.

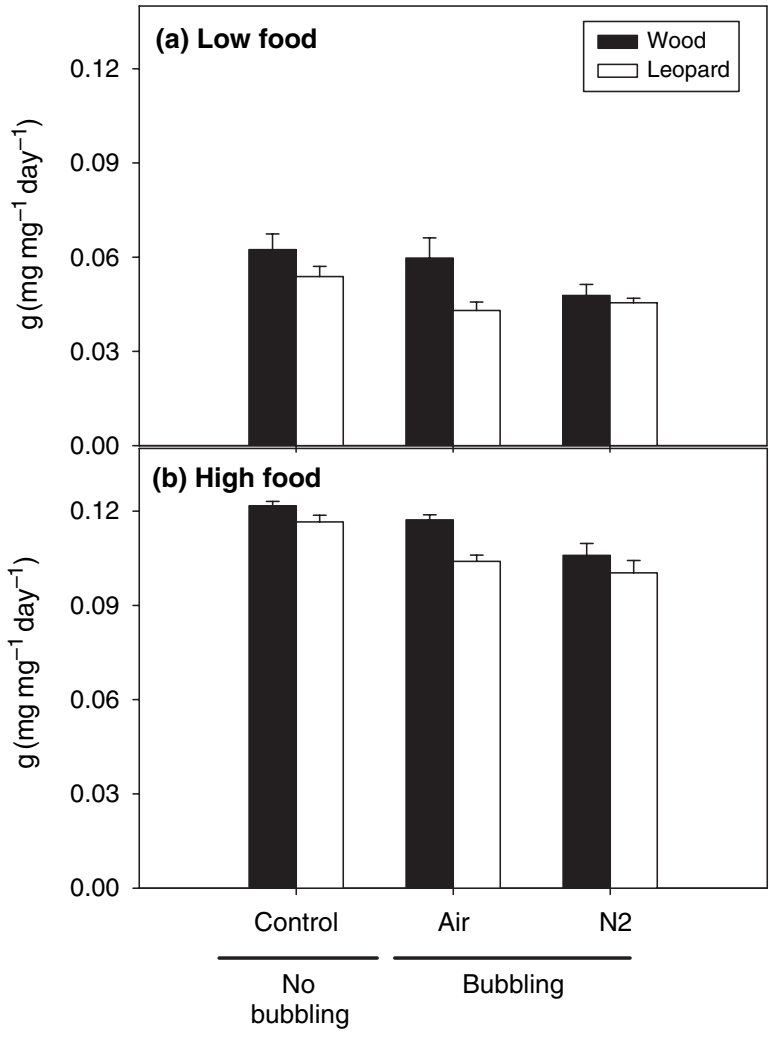

Fig. 6 Specific growth rates of wood frog (solid bars) and leopard frog larvae (open bars) as a function of dissolved oxygen manipulation at (a) low food levels $\left(4 \% \mathrm{BM} \mathrm{day}^{-1}\right)$ and (b) moderately high food levels $\left(12 \% \mathrm{BM} \mathrm{day}^{-1}\right)$. Note that DO was lowest in the nitrogen bubbling treatment $\left(2.2 \pm 0.1 \mathrm{mg} \mathrm{L}^{-1}\right)$, intermediate in the no-bubbling control $\left(6.8 \pm 0.2 \mathrm{mg} \mathrm{L}^{-1}\right)$, and highest in the air bubbling sham control $\left(8.5 \pm 0.1 \mathrm{mg} \mathrm{L}^{-1}, n=\right.$ 16 for each treatment). However, because bubbling itself had an effect on individual performance, the appropriate performance comparison is between manipulations of nitrogen bubbling and air bubbling. Bars represent the grand mean $\pm 1 \mathrm{SE}$ of four replicates.

survivorship decreased from $100 \%$ at air bubbling to $90 \%$ at nitrogen bubbling (Kruskal-Wallis $\chi^{2}=4.9$, d.f. $=1, P=0.027)$. Therefore it appears that wood frogs are more sensitive to decreases in DO than are leopard frogs.

\section{Discussion}

The degree of canopy cover is a gradient with strong impacts on individual performance, population dynamics, and freshwater community structure (Skelly et al., 1999; E.E. Werner, pers. comm.). This study demonstrates that canopy cover influences the performance of anuran larvae, and suggests that resource differences between open- and closed-canopy ponds are of primary importance in mediating these performance effects.

Canopy cover had negative effects on larval performance, as growth and development were slower in closed-canopy ponds than in open-canopy ponds. However, these effects were asymmetrical. The canopy cover generalist, the wood frog, suffered a small reduction in growth rates $(-20 \%)$ in closed-canopy ponds relative to open-canopy ponds. In contrast, the leopard frog, an open-canopy pond specialist, outperformed wood frogs in open-canopy ponds but suffered a large reduction in growth rates $(-46 \%)$ when transplanted to closed-canopy ponds. Furthermore, canopy cover had virtually no effect on wood frog development, but considerably delayed development in leopard frogs. Finally, whereas my experimental design did not allow accurate estimates of mortality, Werner \& Glennemeier (1999) found that wood frogs survived well in both pond types, but leopard frog mortality increased dramatically in closed-canopy ponds.

There are several environmental factors potentially responsible for the reduction in larval performance in closed-canopy ponds, including lower temperature, lower DO, and lower resource quantity and nutritional quality (Werner \& Glennemeier, 1999; Skelly 
et al., 2002; this study). Each of these factors is expected to influence wood frogs and leopard frogs in the same direction. Therefore, the most important factors are those that explain why both species grow faster in open-canopy ponds, but especially why leopard frogs grow faster than wood frogs in this habitat.

Closed-canopy ponds displayed lower DO levels than open-canopy ponds. In the laboratory I found support for the hypothesis that a decrease in DO leads to a reduction in larval growth, as well as to a reduction in survivorship. However, these effects were small and observed for the wood frog only. Therefore, it is unlikely that DO contribute substantially to species performance in the field. Most importantly, DO does not appear to be important in mediating the strong interspecific differences in performance across the gradient because the more DO-sensitive species is the species that colonises hypoxic ponds.

Closed-canopy ponds were also cooler than opencanopy ponds. I found support for the hypothesis that a decrease in temperature is associated with a marked reduction in growth rates; however, species responses were identical. Because temperatures manipulated in the laboratory $\left(14-24{ }^{\circ} \mathrm{C}\right.$ ) bracketed the highest (afternoon) temperatures in ponds during the course of the experiment (WWB: $16.9{ }^{\circ} \mathrm{C}$, SWW: $16.9^{\circ} \mathrm{C}$, FH: $20.1^{\circ} \mathrm{C}$; no data available for IND), I can roughly estimate the contribution of temperature for growth differences in the field. Using slopes of regressions of specific growth rates as function of temperature at the highest food level manipulated in the laboratory experiment (Fig. 5b, slope $=0.0062$ for wood frogs and 0.0058 for leopard frogs), a $3.2{ }^{\circ} \mathrm{C}$ increase in temperature would lead to an increase in specific growth rates of $0.020 \mathrm{mg} \mathrm{mg}^{-1}$ day $^{-1}$ for wood frogs and $0.018 \mathrm{mg} \mathrm{mg}^{-1} \mathrm{day}^{-1}$ for leopard frogs. Therefore, the recorded temperature difference could account for almost $80 \%$ of the actual $0.025 \mathrm{mg} \mathrm{mg}^{-1}$ day $^{-1}$ enhancement of growth of wood frogs, but only $25 \%$ of the actual $0.072 \mathrm{mg} \mathrm{mg}^{-1}$ day $^{-1}$ enhancement of growth of leopard frogs in open-canopy ponds relative to closed-canopy ponds. In conclusion, temperature may partly explain why individuals of both species and especially of wood frogs grow faster in opencanopy ponds. However, neither temperature nor DO can be primarily responsible for the strong interspecific differences in growth performance across the canopy-cover gradient.
An important finding of this study is that canopy cover creates a gradient in resource nutritional quality. An approximate estimate of the protein content of food ingested in nature suggests that foods in opencanopy ponds have $48 \%$ higher quality than in closedcanopy ponds $(37 \%$ versus $25 \%$ protein content; estimated by multiplying $\% \mathrm{~N}$ by 6.25 ; Sterner \& Elser, 2002). This probably occurs because detritus, which accounts for the largest volumetric fraction of gut contents, is of higher quality in open-canopy ponds; and because filamentous algae are more frequently consumed in open-canopy ponds than in closed-canopy ponds. Invertebrates are also important sources of nutrition for free-ranging tadpoles in closed-canopy ponds; however invertebrates are not consumed frequently enough to raise the average quality of food ingested in closed-canopy ponds to open-canopy pond levels (Schiesari, 2004).

In the laboratory, food quality was the only factor that led both to an overall increase in growth rates, and to an increase in growth rates of leopard frogs relative to wood frogs. Furthermore, the close resemblance of species responses to food quality in the laboratory (Fig. 4) and in the field (Fig. 2) suggests that resource nutritional quality is of primary importance in mediating species performances across the canopy cover gradient. These results do not necessarily negate the importance of resource quantity. For instance, no interspecific differences in performance were observed in experiments manipulating small and moderately high food quantities (Figs 5 and 6), but over broader food quantity ranges, growth curves similar to those observed in Fig. 4 are obtained (Schiesari, 2004). Nevertheless, I suggest that food quality is of greater influence on species performances because in closed-canopy ponds several layers of decomposing leaf-litter line the benthos, implying that closed-canopy ponds have an abundant resource - detritus - but this resource is not acquired and processed efficiently by all species. Wood frogs were able to ingest higher quality food than leopard frogs in the closed-canopy pond possibly because of interspecific differences in the functional morphology of oral structures. Wood frogs have two additional keratinised tooth rows (labial tooth row formula (LTRF) 3/4; Altig, 1970) and flat jaw sheaths, as compared with leopard frogs, which have a LTRF of $2 / 3$ and more curved jaw sheaths. These differences in design may lead to higher 
efficiency of the wood frog in extracting the shallow, higher quality biofilm present on leaf surfaces. In addition, wood frogs were found to have higher assimilation efficiency, and to grow faster than leopard frogs when fed detritus irrespective of food quantity (Schiesari, 2004). This greater efficiency in acquiring and processing a poor-quality but abundant food type may explain why wood frogs experience a comparatively minor performance advantage relative to leopard frogs when transplanted to opencanopy ponds, or to food addition treatments in closed-canopy ponds (Werner \& Glennemeier, 1999; Skelly et al., 2002; this study). Summarising, I suggest that it is food quality (nutritional quality per se, plus structure and digestibility) and not quantity that is depressing leopard frog performance in closed-canopy ponds. Such a predominant effect of food quality over food quantity in mediating species performances has received considerable support in zooplankton (Desmarais \& Tessier, 1999; DeMott \& Tessier, 2002; Tessier \& Woodruff, 2002), and it is a central component of ecological stoichiometry that the relative proportions of elements (i.e. nutrients) in diets strongly contribute to species relative and absolute performances (Sterner \& Elser, 2002).

Colonisation of closed-canopy ponds comes at the cost of reduced fitness for anurans, both through direct mortality, and indirectly through decreased growth rates and prolonged developmental period (Werner \& Glennemeier, 1999; Skelly et al., 2002; this study). Slow growth is correlated with lower fitness because slow growing individuals tend to take longer to reach, and to achieve lower masses at, metamorphosis and maturity (Berven \& Gill, 1983; Berven, 1990). In addition, prolonged development indirectly increases the probability of mortality through pond drying (e.g. Skelly et al., 2002). As a corollary, why do wood frogs colonise closed-canopy ponds despite the associated reduction in fitness? Because no other anuran species in the region commonly oviposits in this habitat (Skelly et al., 1999), interspecific competition and egg predation by other tadpoles are lower in closed-canopy ponds. In addition, larval predation risk should be lower as well because dragonfly communities are impoverished in closed-canopy ponds (McCauley, 2005), and because closed-canopy ponds tend to be temporary, and temporary ponds typically lack fish to which wood frog larvae are highly vulnerable (Relyea, 2001).
Light gradients have had an important influence on our understanding of the structure and dynamics of terrestrial communities. This study demonstrates that the same gradient may have major impacts of the individual performance of freshwater organisms, with possibly important demographic and communitylevel consequences. This gradient changes dynamically over time and space as a result of both natural and anthropogenic processes, and changes in pond light regimes are followed by changes in amphibian communities (Skelly et al., 1999). Recognising that food may be a primary factor influencing individual performances can help us predict community-level consequences of modification of light regimes, based on individual nutrient requirements and abilities in exploiting specific food types.

\section{Acknowledgments}

I thank Earl Werner and George Kling for advice, and Mark Brahce, Karen Riseng, Don Zak and Jana Gastellum for the elemental analyses. Michael R. Frederick, Arthur Cooper and Chris Davis helped in the fieldwork. I also thank Faye Stoner, Matthew Heumann and Washtenaw County Parks for permission to work in Independence Marsh. This research was supported by grants from The University of Michigan, the National Science Foundation (NSF-DEB982027 to George Kling), and the Brazilian Government's Conselho Nacional de Desenvolvimento Científico e Tecnológico (200093/975). This manuscript was improved with the comments of Earl Werner, George Kling, David Allan, Deborah Goldberg, Britta Grillitsch, Rick Lehtinen, Mara Zimmerman, and Shannon McCauley.

\section{References}

Alford R.A. (1999) Ecology: resource use, competition, and predation. In: Tadpoles - the Biology of Anuran Larvae (Eds R.W. McDiarmid \& R. Altig), pp. 240-278. The University of Chicago Press, Chicago, IL.

Altig R. (1970) A key to the tadpoles of the continental United. States and Canada. Herpetologica, 26, 180-207.

Augspurger C.K. (1984) Light requirements of neotropical tree seedlings: a comparative study of growth and survival. Journal of Ecology, 72, 777-795.

Berven K.A. (1990) Factors affecting population fluctuations in larval and adult stages of the wood frog (Rana sylvatica). Ecology, 71, 1599-1608. 
Berven K.A. \& Gill D.E. (1983) Interpreting geographic variation in life-history traits. American Zoologist, 23, 85-97.

Burggren W.W. \& Just J.J. (1992) Developmental changes in physiological systems. In: Environmental Physiology of the Amphibians (Eds W.E. Feder \& W.W. Burggren), pp. 467-530. The University of Chicago Press, Chicago, IL.

Bussler H. (1982) Waldgewasser als Lebensraum. Natur und Landschaft, 57, 128-132.

Clements F.E. (1916) Plant Succession: an Analysis of the Development of Vegetation. Carnegie Institution of Washington, Washington, DC.

Connell J.H. (1975) Some mechanisms producing structure in natural communities: a model and evidence from field experiments. In: Ecology and Evolution of Communities (Eds M.L. Cody \& J.M. Diamond), pp. 460-490. The Belknap Press of Harvard University Press, Cambridge, MA.

DeMott W.R. \& Tessier A.J. (2002) Stoichiometric constraints vs. algal defenses: testing mechanisms of zooplankton food limitation. Ecology, 83, 3426-3433.

Desmarais K.H. \& Tessier A.J. (1999) Performance tradeoff across a natural resource gradient. Oecologia, 120, 137-146.

Eckert R. \& Randall D. (1983) Animal Physiology Mechanisms and Adaptations. W. H. Freeman and Company, San Francisco, CA.

Feder M.E. (1984) Consequences of aerial respiration for amphibian larvae. In: Respiration and Metabolism of Embryonic Vertebrates (Ed. R.S. Seymour), pp. 71-86. D.W. Junk Publ., Dordrecht, The Netherlands.

Feder M.E. \& Moran C.M. (1985) Effect of water depth on costs of aerial respiration and its alternatives in tadpoles of Rana pipiens. Canadian Journal of Zoology, 63, 643-648.

Gosner K.L. (1960) A simplified table for staging anuran embryos and larvae, with notes on identification. Herpetologica, 16, 183-190.

Halverson M.A., Skelly D.K., Kiesecker J.M. \& Freidenburg L.K. (2003) Forest mediated light regime linked to amphibian distribution and performance. Oecologia, 134, 360-364.

Horn H.S. (1974) The ecology of secondary succession. Annual Review of Ecology and Systematics, 5, 25-37.
Canopy cover - a freshwater resource gradient

Kobe R.K., Pacala S.W. \& Silander J.A. Jr (1995) Juvenile tree survivorship as a component of shade tolerance. Ecological Applications, 5, 517-532.

McCauley S.J. (2005) Species distributions in anisopteran odonates: effects of local and regional processes. PhD Dissertation, The University of Michigan, Ann Arbor, Michigan.

McIntyre P.B. \& McCollum S.A. (2000) Responses of bullfrog tadpoles to hypoxia and predators. Oecologia, 125, 301-308.

Menge B.A. \& Sutherland J.P. (1976) Species-diversity gradients - synthesis of roles of predation, competition, and temporal heterogeneity. American Naturalist, 110, 351-369.

Menge B.A. \& Sutherland J.P. (1987) Community regulation - variation in disturbance, competition, and predation in relation to environmental stress and recruitment. American Naturalist, 130, 730-757.

Relyea R.A. (2001) The relationship between predation risk and antipredator responses in larval anurans. Ecology, 82, 541-554.

Schiesari L.C. (2004) Performance tradeoffs across resource gradients in anuran larvae. PhD Dissertation, The University of Michigan, Ann Arbor, Michigan.

Skelly D.K., Freidenburg L.K. \& Kiesecker J.M. (2002) Forest canopy and the performance of larval amphibians. Ecology, 83, 983-992.

Skelly D.K., Werner E.E. \& Cortwright S.A. (1999) Longterm distributional dynamics of a Michigan amphibian assemblage. Ecology, 80, 2326-2337.

Sterner R.W. \& Elser J.J. (2002) Ecological Stoichiometry: the Biology of Elements from Molecules to the Biosphere. Princeton University Press, Princeton, NJ.

Tessier A.J. \& Woodruff P. (2002) Trading off the ability to exploit rich versus poor food quality. Ecology Letters, 5, 685-692.

Wellborn G.A., Skelly D.K. \& Werner E.E. (1996) Mechanisms creating community structure across a freshwater habitat gradient. Annual Review of Ecology and Systematics, 27, 337-363.

Werner E.E. \& Glennemeier K. (1999) The influence of forest canopy cover on the breeding pond distributions of several amphibian species. Copeia, 1, 1-12.

(Manuscript accepted 7 November 2005) 